\title{
Grassland farming and minerals in cattle
}

\author{
A. Kemp and J. H. Geurink \\ Centre for Agrobiological Research (CABO), Wageningen, the Netherlands
}

Accepted: 27 September 1977

Key words: minerals, milking cows, nitrate poisoning, mineral requirements, mineral supply, mineral deficiency

\section{Summary}

In this paper data on the mineral composition of grass of intensively managed farms is compared with the requirement of minerals of high-yielding milking cows. Attention is also paid to the way in which the mineral supply to cattle can be assessed and how possible deficiencies can be prevented. Finally, the effect of nitrogen fertilizer on the nitrate content in grass and other roughages is discussed in relation to the origin and prevention of nitrate poisoning in cattle.

\section{Introduction}

In Western Europe the rations of dairy cows during the growing season consist mainly or entirely of fresh grass. Moreover, grass silage, hay or artificially dried grass are often important components of the winter rations. Therefore, close attention should be paid to the composition of the grass for dairy cows to remain in a good condition with a high milk yield. Fertilizer application, botanical composition and stage of growth, soil type and climate are factors which may have a considerable effect on the composition of the herbage. These factors cause great diversity in the mineral content. This means that this wide variation should always be allowed for in comparing the mineral contents in the grass with the requirement of them in highyielding milking cows.

\section{Mineral composition of herbage, intake and excretion of minerals by milking cows}

Table 1 shows data of Keuning (1974) on the mineral composition of 746 grass samples taken on 22 intensively managed grassland farms on sand, clay and peat soils in the Netherlands from 1962 including 1971. The herbage was usually sampled at a length of some $15 \mathrm{~cm}$ and throughout the growing season. The average crude protein content was $25.1 \pm 4.1 \%$ in the dry matter. Nitrogen fertilizer application varied from 250 to $350 \mathrm{~kg}$ of $\mathrm{N}$ as ammonium nitrate limestone ha-1 year $^{-1}$. The swards of these permanent pastures consisted of $90 \%$ or over of 
Table 1. Mineral composition of herbage, the intake by lactating cows consuming $16 \mathrm{~kg}$ of dry matter, the daily excretion in milk, faeces and urine and the percentage of intake not excreted in the faeces ‘apparent availability).

\begin{tabular}{|c|c|c|c|c|c|c|c|c|}
\hline \multirow[t]{2}{*}{ Element } & \multicolumn{2}{|c|}{ Dry matter in herbage $(\%)$} & \multirow{2}{*}{$\begin{array}{l}\text { Daily } \\
\text { intake (g) }\end{array}$} & \multicolumn{3}{|c|}{ Daily excretion $(\mathrm{g})$} & \multicolumn{2}{|c|}{ Availability (\%) } \\
\hline & mean & $\sigma \mathrm{x}$ & & $\begin{array}{l}25 \mathrm{~kg} \text { of } \\
\text { milk }\end{array}$ & faeces & urine & mean & $\begin{array}{l}\text { highest- } \\
\text { lowest }\end{array}$ \\
\hline $\mathbf{K}$ & 3.02 & 0.65 & 483 & 41.3 & 53.1 & 388.6 & 89 & $80-95$ \\
\hline $\mathrm{Na}$ & 0.37 & 0.22 & 59.2 & 10.0 & 8.9 & 40.3 & 85 & $66-92$ \\
\hline $\mathrm{Cl}$ & 1.08 & 0.39 & 173 & 28.8 & 20.8 & 123.4 & 88 & $71-95$ \\
\hline $\mathbf{S}$ & 0.42 & 0.07 & 67.2 & 7.5 & 18.1 & 41.6 & 73 & $64-82$ \\
\hline $\mathrm{Ca}$ & 0.61 & 0.10 & 97.6 & 30.0 & 68.3 & 0.5 & 30 & $16-47$ \\
\hline $\mathrm{Mg}$ & 0.23 & 0.05 & 36.8 & 3.0 & 30.5 & 3.3 & 17 & $7-33$ \\
\hline $\mathrm{P}$ & 0.41 & 0.07 & 65.6 & 23.8 & 47.9 & 0.2 & 27 & $10-46$ \\
\hline
\end{tabular}

grasses with a very low percentage of clover. The contents of calcium and magnesium will be higher in those pastures with more clovers and herbs. The standard deviations show that the contents vary widely.

The secretion of various minerals in the milk and the excretion of the minerals in the faeces and urine was calculated with data on balance experiments with 44 lactating cows, Kemp (1966). The results show distinctly that potassium, sodium, chlorine and sulphur are mostly excreted in the urine, while calcium, magnesium and phosphorus mainly occur in the faeces. Especially, the latter minerals show a very wide percentual variation in apparent availability.

\section{Mineral requirement of grazing high-yielding milking cows}

\section{Potassium, sodium and chlorine}

Unlike with sodium and chlorine, grassland needs a regular potassium application in order to obtain a good herbage production. The herbage potassium contents are much higher than necessary to meet the requirements of highly productive milking cows. The potassium content in the milk is $1.65 \mathrm{~g}$ per litre. With a normal dry matter intake, the potassium requirement for maintenance and for the production of a daily milk yield of 25 litres could be met by $0.50 \%$ potassium in the dry matter of the feed. Table 1 shows that even the lowest potassium contents are higher than $0.50 \%$.

This also holds for the element chlorine, although to a less extent. The chlorine content in milk is $1.15 \mathrm{~g}$ per litre. Short-term and long-term feeding trials with highproducing dairy cows (Kemp et al., unpublished data) led to the conclusion that with a milk yield of 25 litres per day the chlorine requirement is met, when the feed contains 0.30 to $0.35 \%$ of chlorine. Table 1 shows that the average chlorine content in the herbage is about three times higher than this requirement and that in only few cases the contents are so low that they approach this level.

Unlike the contents of potassium and chlorine, the content of sodium in pasture grass is not always sufficient to meet the requirement of milking cows. Supplying 
herbivora with additional salt is a very old custom in many areas. The sodium content in the milk is $0.40 \mathrm{~g}$ per litre. The requirement for maintenance and production of an adult milking cow is $6.0 \mathrm{~g}$ of dietary sodium per day and $0.50 \mathrm{~g}$ per litre of milk (Kemp, 1964). With a milk yield of 25 litres a day the sodium requirement is adequately met with a normal dry matter intake, when the sodium content in the rations is $0.15 \%$ (Smith \& Aines, 1959; Kemp, 1964, 1966). Comparison of this content with the sodium content in herbage, as mentioned in Table 1, leads to the conclusion that allowing for a variation in the herbage sodium of two times the standard deviation below and above the average content, in many cases the sodium content is too low to meet the requirements.

However, ruminants have ways of delaying the consequences of deficient supply. Immediately after cutting the sodium supply, excretion in the urine falls sharply. When daily excretion falls below 3 or $2.5 \mathrm{~g}$, the balance turns negative total losses being greater than dietary supply. Depletion of sodium from the body begins, particularly manifested as a fall in the sodium level in saliva and a corresponding rise in potassium. The composition of rumen fluid changes in like manner most of its sodium being derived from saliva. This sodium acts as a mobile reserve that can be drawn on in periods of deficient supply. This reserve allows even highly productive cows to be fed for several months on a sodium deficient diet without clinical signs. However, when this reserve is depleted the cow shows depressed appetite, produces less milk, loses weight, tends to lick objects and has a dry staring coat.

Because of its reaction to deficiency, long before clinical signs appear, the best criterion for assessment of the sodium status is the concentration of sodium and potassium in saliva (see Table 2).

Besides advice on direct supplementation to deficient cattle, ways should be found of avoiding sodium deficiency by certain dressing measures. By means of dressing grassland with a sodium containing fertilizer, the herbage sodium content can be increased easily. The effect of this dressing will be smaller as more potassium is applied at the same time.

\section{Calcium and phosphorus}

Potassium, sodium and chlorine are resorbed from the gastro-intestinal tract to a relatively great extent and a supply in excess of requirement for maintenance and production is excreted in the urine. With calcium and phosphorus, however, also with a high dietary supply, little is excreted in the urine. The amount not excreted in the faeces increases as the requirement for milk production increases (see Table

Table 2. Tentative criteria of the sodium status from the concentration in saliva $(\mathrm{mg} / 100 \mathrm{ml})$.

\begin{tabular}{rrl}
\hline $\mathrm{Na}$ & $\mathrm{K}$ & \\
$>300$ & $<50$ & Sufficient \\
$300-200$ & $50-150$ & Insufficient, without clinical signs \\
$200-100$ & $150-250$ & Insufficient, clinical signs may occur \\
$<100$ & $>250$ & Severe deficiency, clinical signs occur \\
\hline
\end{tabular}


Table 3. Mean apparent availabilities of calcium ( 965 exp.) and phosphorus ( $953 \mathrm{exp}$.) in milking cows producing different amounts of milk, led on rations containing increasing amounts of calcium or phosphorus.

\begin{tabular}{|c|c|c|c|c|c|c|c|}
\hline \multirow{2}{*}{$\begin{array}{l}\text { Milk production } \\
\left(\mathrm{kg} \text { day }^{-1}\right)\end{array}$} & \multicolumn{7}{|c|}{ Intake of calcium $\left(\mathrm{g} \mathrm{day}^{-1}\right)$} \\
\hline & $10-30$ & $31-50$ & $51-70$ & $71-90$ & $91-110$ & $111-130$ & $>130$ \\
\hline dry & 32 & 23 & 19 & 15 & 12 & & \\
\hline $1-5$ & & 34 & 21 & 20 & 16 & & \\
\hline $6-10$ & & 43 & 30 & 27 & 18 & & \\
\hline $11-15$ & & 50 & 31 & 25 & 20 & 24 & \\
\hline $16-20$ & & 51 & 37 & 26 & 23 & 23 & 20 \\
\hline $21-25$ & & 46 & 37 & 31 & 25 & 23 & \\
\hline $26-30$ & & 48 & 46 & 40 & 33 & 28 & \\
\hline$>30$ & & & & & 44 & & \\
\hline \multirow{2}{*}{$\begin{array}{l}\text { Milk production } \\
\mathrm{kg} \mathrm{day}^{-1}\end{array}$} & \multicolumn{7}{|c|}{ Intake of phosphorus (g day $\left.{ }^{-1}\right)$} \\
\hline & $10-30$ & $31-50$ & $51-70$ & $71-90$ & $91-110$ & $111-130$ & $>130$ \\
\hline dry & 17 & 16 & 14 & & & & \\
\hline $1-5$ & & 19 & 18 & & & & \\
\hline $6-10$ & 36 & 29 & 22 & & & & \\
\hline $11-15$ & 44 & 38 & 24 & 24 & & & \\
\hline $16-20$ & & 42 & 29 & 26 & 26 & & \\
\hline $21-25$ & & 44 & 32 & 28 & 27 & 21 & \\
\hline $26-30$ & & 46 & 45 & 32 & 29 & & \\
\hline$>30$ & & & & & & 29 & \\
\hline
\end{tabular}

3). Table 3 summarizes data from the literature on 965 conventional balance experiments on calcium and 953 on phosphorus from the period 1920 to 1960. The available data were divided into classes of $\mathrm{Ca}$ and $\mathrm{P}$ intake and into classes of milk production. At the end of lactation all the cows were pregnant. From the data within one class the average percentage was calculated of the $\mathrm{Ca}$ and $\mathbf{P}$ intake not excreted in the faeces (apparent availability). Urine and faeces were not separately collected in all the experiments. However, the concentration of urinary calcium and phosphorus is so low compared to that excreted in the faeces that its effect on the mentioned average percentages is negligible. These roughly summarized data clearly show that with equal $\mathrm{Ca}$ or $\mathrm{P}$ intake with the feed, apparent availability increases at increasing milk yields. At constant milk productions with an increasing $\mathrm{Ca}$ and $\mathrm{P}$ intake the excess of $\mathrm{Ca}$ and $\mathrm{P}$ is excreted in the faeces. This agrees with urinary $\mathrm{Ca}$ and $\mathrm{P}$ neither increasing with high intakes of $\mathrm{Ca}$ and $\mathrm{P}$, as mentioned before. Balance experiments combined with ${ }^{45} \mathrm{Ca}$ radio activity measurements also indicated that true availability of $\mathrm{Ca}$ decreases with increasing calcium intake (Comar et al., 1953). Van 't Klooster (1977) concluded from balance trials with ${ }^{45} \mathrm{Ca}$ that with a calcium secretion in the milk of 10 and $35 \mathrm{~g}$ a day absorption efficiency increased from 15 to $40 \%$. The increase in the concentration of non-faecal $\mathrm{Ca}$ and $\mathrm{P}$, however, is not proportional to the increasing requirement at higher milk yields. This seems to be different in cases of high $\mathrm{Ca}$ and $\mathrm{P}$ intakes. Ca and $\mathrm{P}$ balances, not 
mentioned here, are more negative at high milk yields with low intake than with high intake. However, conclusions on this can only be drawn, when the stage of lactation is also taken into account. It seems worthwhile to compute these many data statistically in more detail.

From the data in the literature it may be concluded that a negative calcium and phosphorus balance at the beginning of lactation is physiologically normal. However, the important question as to how far the body reserves of $\mathrm{Ca}$ and $\mathrm{P}$ can be depleted, without possible adverse effects, cannot be answered sufficiently. In the Netherlands the advice on the calcium and phosphorus supply to milking cows is based on equality of intake and losses throughout the lactation cycle, accepting a certain maximum loss of calcium and phoshorus during the first part of lactation. These standards are in fair agreement with those of ARC and NRC. For moderately productive cows with annual milk yields of $4500 \mathrm{~kg}$, the $\mathrm{Ca}$ and $\mathrm{P}$ content in the rations should be 0.45 and $0.35 \%$, respectively. The standards should be treated as a rough approximation, because of the arbitrary maxima for losses of calcium and phosphorus from reserves in the first part of lactation.

Insufficient absorption of calcium from the diet and insufficient mobilization of this element from bone after parturition may lead to a sereous fall in the blood calcium content and the occurrence of milk fever. The recent literature, such as Ramberg et al. (1972), suggests that feeding low calcium diets prepartum improves the rate of release of calcium from the bone and the absorption of calcium from the gut during the 2-3 days critical period after parturition. Several workers suggest that feeding low calcium diets prepartum would be helpful to prevent milk fever (Westerhuis, 1973). However, it is by no means certain that this can be realized in practice with a view to the high calcium content in the rations compared to the low requirement of dry cows.

When the advised calcium and phosphorus contents in the rations are compared with the concentrations mentioned in Table 1 , it may be concluded that during pasturing the supply of these elements will be sufficient. Even the lowest contents may be just sufficient, due to the appreciable increase in absorption efficiency at low intakes. Modern methods of farming tend to reduce values in pastures, especially those of calcium. Calcium in pastures can be increased only by increasing the proportion of clover and herbs. The effect of liming the soil with consequent rise in soil $\mathrm{pH}$ is negligible. Potassium fertilizers and an excess of potassium in the soil lower the calcium level in pasture grass. Magnesium dressing also lowers the calcium level, particularly on sandy soils. Nitrogen fertilizer acts on the phosphorus content of herbage through its effect on the crude protein content; the phosphorus content falls markedly as the herbage matures. When plant growth is not limited by the phosphorus status of the soil, phosphate fertilizer will only affect the phosphorus content in the herbage slightly.

\section{Magnesium}

Unlike with calcium and phosphorus, for example, adult cattle only have a very small body reserve of mobilizable magnesium to draw on in times of deficient supply. Hypomagnesaemia and hypomagnesaemic tetany may occur therefore within a few 
days, as a result of a shortage of magnesium caused by a reduction in the dietary supply of available magnesium (Rook \& Balch, 1958; Kemp et al., 1961). The daily dry matter intake and its magnesium content, and the utilization of the ingested magnesium are the important factors. Studies with fistulated cows (Rogers \& van 't Klooster, 1969) and with sheep (Grace, 1972) have indicated that the main site of magnesium absorption is proximal to the duodenum.

Averaged data on 44 dairy cows (Table 1 ) show that $17 \%$ of the magnesium intake was not excreted in the faeces, within a range of 7 to $33 \%$. A shortage of available magnesium is immediately followed by a sharp fall in urinary magnesium. In contrast to calcium and phosphorus there is a close relation between dietary supply of available magnesium and urinary excretion of it. When urinary magnesium excretion is about $2.5 \mathrm{~g}$ a day, magnesium intake and excretion wil be at equilibrium. Lower urinary excretion is related to negative retention, with an excretion below $1 \mathrm{~g}$ per day serum magnesium contents may drop from $2.5 \mathrm{mg}$ per $100 \mathrm{ml}$ to below $1.0 \mathrm{mg}$, at which level clinical signs may occur of hypomagnesaemic tetany. Urinary magnesium excretion is a better criterion for determining the magnesium status of the animal than is the serum magnesium content. The available feed magnesium can be estimated more accurately and a shortage can be observed sooner. Even a determination of the magnesium content in a sample of urine taken at any time of the day, gives sufficient information on the magnesium supply to the animal. Normal serum magnesium contents were found in a great number of milking cows, when the concentration of magnesium in the urine was $100 \mathrm{mg}$ per litre or higher. On the other hand, sub-normal or low values were found, when the urinary magnesium concentration dropped below $50 \mathrm{mg}$ per litre.

The daily requirement of available magnesium is $2.5 \mathrm{~g}$ for maintenance and $0.12 \mathrm{~g}$ per litre of milk. The required dietary magnesium to be calculated from these data is, however, very dependent on the widely varying values for availability. With an availability of 10,20 or $30 \%$ the requirement of dietary magnesium of a cow yielding 25 litres of milk per day is 55,28 or $18 \mathrm{~g}$ per day, respectively. With a dry matter intake of $16 \mathrm{~kg}$ a day and availability being $17 \%$ (Table 1), a magnesium content of $0.20 \%$ will suffice. A higher magnesium content will be necessary in very young herbage, whereas a somewhat lower content will suffice in older herbage.

In comparing these advised herbage contents with the average content and variation mentioned in Table 1 , it has to be concluded that with a view to the variation and the low values for availability in young grass, the magnesium supply in many cases will be insufficient without magnesium supplementation. Also because adult cows do not have a mobilizable magnesium reserve in the body, continuous attention will have to be paid to the magnesium supply, especially on the intensively managed farms, in order to prevent the occurrence of hypomagnesaemia and hypomagnesaemic tetany. Increasing the availability of the herbage magnesium content is not effective enough, since a high grassland production and pasturing herbage at a young stage are related to low availability. Preventative measures should be directed therefore at raising the daily magnesium intake. Heavy potassium dressings decrease the herbage magnesium content and with a high dietary potassium intake more magnesium is excreted in the faeces. Especially on the light sandy 
soils a regular magnesium dressing may increase the herbage magnesium content considerably. The most efficient preventive measure is, however, a daily oral supply of about $30 \mathrm{~g}$ of supplementary magnesium. This may take place by suppling magnesium rich concentrates or by dusting the herbage with magnesium oxide, just before pasturing.

\section{Utilization of herbage nitrogen by grazing milking cows and the incidence of nitrate poisoning}

In the Netherlands nitrogen dressings to grassland have increased from about $50 \mathrm{~kg}$ to $225 \mathrm{~kg}$ of nitrogen fertilizer per ha per year, during the last 25 years. This management has increased the grassland production by about $40 \%$ to an average of some $11000 \mathrm{~kg}$ of dry matter per ha per year (Jagtenberg, 1975). About $70 \%$ of the total grass production is used for pasturing, especially with milking cows. A high milk yield per grazing cow with the lowest possible supply of concentrates can only be attained by the consumption of high-energy feed and therefore young pasture grass. However, with increasing nitrogen dressings this leads to the pasture grass containing far too much more crude protein than needed to meet the requirements of the cows. With a nitrogen dressing of about $225 \mathrm{~kg} \mathrm{~N}$ per ha the protein excess in pasturing highly productive milking cows will average some $1000 \mathrm{~g}$ of crude protein per cow per day throughout the grazing period. This crude protein is, however, used as an energy source. When grazing with beef cattle this protein excess will be still greater.

Increasing grassland production by means of nitrogen dressing leads to increasing nitrate contents in the herbage. In the 746 grass samples of the same 22 intensively managed farms the nitrate content was $0.64 \pm 0.41 \% \mathrm{NO}_{3}$ in the dry matter. However, it is possible that contents up to $1.50 \% \mathrm{NO}_{3}$ occur. Especially on heavily dressed young grassland the nitrate contents may be much higher.

Nitrate poisoning in pasturing cattle, however, occurs rarely or not at all in the Netherlands. Two factors are of importance in this: during grazing dry matter intake is slower, and the nitrate from fresh grass is released slower in the rumen than that from hay and that from turnips. Cases of nitrate poisoning occur regularly in feeding turnips, forage rape or hay or wilted silage in which nitrate contents may rise to over $6.00 \% \mathrm{NO}_{3}$ in the dry matter. These roughages were usually grown on fields excessively dressed with organic manure, frequently supplemented with nitrogen fertilizer.

In the rumen of ruminants micro-organisms can reduce nitrate to ammonia and nitrite is an intermediate in this reaction. The nitrite is partly absorbed from the rumen and converts haemoglobin in the blood to methaemoglobin, reducing oxygen transportation. If more than $50 \%$ of the haemoglobin is converted to methaemoglobin, desease symptoms may occur (Crawford, 1960). The symptoms are: discolouration of the skin and mucous membranes, drowsiness, muscle tremors, quickened pulse and respiration, sometimes blindness and a staggering gate. In the last stages the animals fall down and offer little resistance. The often speedy course 
of the poisoning means that in many cases treatment by the veterinarian comes too late.

When the animals are fed twice daily on roughage with a high nitrate content, the highest methaemoglobin contents in the blood are to be expected 3 to 5 hours after the cows started feeding. The decrease afterwards takes place at a much slower rate and therefore the methaemoglobin contents at the next feeding have not yet attained the normal level. By observing the vaginal mucous membranes at an early stage, it can be decided whether or not a certain feed is risky (Kemp et al., 1976). This method also allows to establish whether the preventive measures applied were sufficiently effective. The methaemoglobin contents remain at a normal or almost normal level, when only 3 to $4 \mathrm{~g}$ of $\mathrm{NO}_{3}$ per $100 \mathrm{~kg}$ body weight are supplied per feed. If $15 \mathrm{~g}$ or more are supplied, the risk is great that over $50 \%$ of the haemoglobin is converted to methaemoglobin and that deaths occur. When nitrate rich feed is supplied after a period with nitrate poor roughages, considerably less methaemoglobin is formed immediately after the change than on the third and following days. This rise is probably due to a change in the activity of the reducing micro-organisms in the rumen (Kemp et al., 1977).

High nitrate contents in the roughage are caused by more nitrogen being absorbed by the plant than necessary for a maximum dry matter production. Application of excessive dressings, especially in crops liable to accumulate nitrate, like turnips and forage rape, should be prevented. If after all roughages are harvested with a too high nitrate content, the just mentioned concentrations of nitrate per feed should not be exceeded.

\section{Résumé}

On a comparé la composition minérale de l'herbe d'exploitations bien intensives au besoin des vaches laitières de haute productivité. Ensuite l'auteur a discuté la manière de juger la satisfaction des besoins minéraux des animaux et la manière de prévenir des déficits eventuels.

Pour conclure on a discuté l'influence de la fumure azotée sur la teneur en nitrate d'herbes et d'autres plantes fourragères en relation avec l'origine et l'empêchement d'empoisonnement du bétail par le nitrate.

\section{References}

Comar, C. L., R. A. Monroe, W. J. Visek \& S. L. Hansard, 1953. Comparison of two isotope methods for determination of endogenous fecal calcium. J. Nutr. 50: 459-467.

Crawford, R., 1960. Some effect of nitrate in forage in ruminant animals. $\mathrm{Ph}$. D. Thesis, Cornell University, Ithaca, New York, p. 1-156.

Grace, N. D., 1972. Influence of feeding regimen and protein supplementation on the sites of net absorption of magnesium in sheep. Br. J. Nutr. 27: 51.

Jagtenberg, W. D., 1975. Verhoging van de graslandproduktie noodzakelijk en mogelijk. $B e$ drijfsontwikkeling 6: 413-417.

Kemp, A., W. B. Deys, O. J. Hemkes \& A. J. H. van Es, 1961. Hypomagnesaemia in milking cows: intake and utilization of magnesium from herbage by lactating cows. Neth. J. agric. Sci. 9: 134-149. 
Kemp, A., 1964. Sodium requirement of milking cows: Balance trials with cows on rations of freshly mown herbage and on winter rations. Neth. J. agric. Sci. 12: 263-280.

Kemp, A., 1966. Mineral balance in dairy cows fed on grass, with special reference to magnesium and sodium. Proc. 10th int. Grassld. Congr.: 411-414.

Kemp, A. \& J. H. Geurink, 1966. Further information on the sodium requirement and sodium supply of lactating cows. Tijdschr. Diergeneesk. 91: 580-613.

Kemp, A., J. H. Geurink, R. T. Haalstra \& A. Malestein, 1976. Nitrate poisoning in cattle. 1. Discolouration of the vaginal mucous membrane as aid in the prevention of nitrate poisoning in cattle. Stikstof 19: 40-48.

Kemp, A., J. H. Geurink, R. T. Haalstra \& A. Malestein, 1977. Nitrate poisoning in cattle. 2. Changes in nitrite in rumen fluid and methemoglobin formation in blood after high nitrate intake. Neth. J. agric. Sci. 25: 51-62.

Keuning, J. A., 1974. De voederwaarde en de minerale samenstelling van weidegras op de stikstofproefbedrijven in de jaren 1962-1971. Stikstof 76: 87-101.

Klooster, A. Th. van 't, 1977. Adaptation of calcium absorption from the gut of cows at the onset of lactation. Proc. 3rd int. Conf. Prod. Dis. Farm anim.: 108-110. Pudoc, Wageningen.

Ramberg, C. F., Jr., G. P. Mayer, D. S. Kronfeld, J. M. Phang \& M. Berman, 1970. Calcium kinetics in cows during late pregnancy, parturition and early lactation. Am. J. Physiol. 219: 1166-1177.

Rogers, P. A. M. \& A. Th. van 't Klooster, 1969. The fate of $\mathrm{Na}, \mathrm{K}, \mathrm{Ca}, \mathrm{Mg}$ and $\mathrm{P}$ in the digesta. Meded. LandbHogesch. 69-11: 26.

Rook, J. A. F. \& C. C. Balch, 1958. Magnesium metabolism in the dairy cow. II. Metabolism during the spring grazing season. J. agric. Sci. 51: 199-207.

Smith, S. E. \& P. D. Aines, 1959. Salt requirements of dairy cows. Bulletin 938, Cornell University, Ithaca, New York.

Westerhuis, J. H., 1974. Parturient hypocalcaemia prevention in parturient cows prone to milk fever by dietary measures. Agric. Res. Rep. 814. Pudoc, Wageningen. 